\title{
PERCEPTION OF HEPATITIS B AND ADULT HEPATITIS B VACCINATION: A PILOT STUDY AMONG MALAYSIAN HOUSEHOLDS USING MALAY VERSION QUESTIONNAIRE
}

\author{
Yogambigai Rajamoorthy ${ }^{1 *}$, Niazlin Mohd Taib ${ }^{2}$, Harapan Harapan ${ }^{3,4,5}$,Subramaniam Munusamy $y^{6,7}$ \\ Alias Radam ${ }^{6}$ and Khalid Rahim ${ }^{6}$ \\ ${ }^{1}$ Department of Economics, Faculty of Accountancy and Management, Universiti Tunku Abdul Rahman, Cheras, 43000, \\ Malaysia \\ 2Department of Medical Microbiology and Parasitology, Faculty of Medicine and Health Science, Universiti Putra \\ Malaysia, Serdang, 43400, Malaysia \\ ${ }^{3}$ Department of Microbiology, School of Medicine, Universitas Syiah Kuala, Banda Aceh, 23111, Indonesia \\ ${ }^{4}$ Medical Research Unit, School of Medicine, Universitas Syiah , Banda Aceh, 23111, Indonesia \\ ${ }^{5}$ Tropical Disease Centre, School of Medicine, Universitas Syiah Kuala, Banda Aceh, 23111, Indonesia \\ ${ }^{6}$ Department of Economics, Faculty of Economics and Management, Universiti Putra Malaysia, Serdang, 43400, \\ Malaysia \\ ${ }^{7}$ School of Management and Business, Manipal International University, Nilai, 71800, Malaysia
}

Corresponding author: Yogambigai Rajamoorthy

Email: yogambigai@utar.edu.my

\begin{abstract}
Hepatitis $B(H B)$ is an upcoming health issue in Malaysia. Even though the Expanded Programme on Immunisation (EPI) for $H B$ vaccination implemented by the Malaysia government in 1989, individuals born before 1989 were not covered under the EPI and should immunised against the HB virus. Examining the Malaysians' perception of vaccination is very important in order to determine their behaviour regarding $H B$ vaccination. Most of the studies only gave priority to analysing this issue from an occupational risk perspective, consumers' perceptions of the HB vaccination are still lacking. This study is aimed at assessing the validity and reliability of the Malay version of the perception questionnaire used for Malaysian households. A pilot study involving 300 respondents was conducted in six districts in the Selangor area. Factor analysis constructed four components: perceived sustainability, perceived severity, perceived benefit and perceived barriers loaded on the corresponding component with factor loading of more than 0.5. Principal component analysis of the finalised 13 items explained the instrument of the variance, which was $59.7 \%$ in total, $20.3 \%, 14.5 \%, 12.5 \%$ and $12.4 \%$ explained by the four constructs. The Cronbach alpha for the items instruments is 0.5 to 0.8 which shows that moderate internal consistency exists and demonstrates reliability of the questionnaire. The frequency of the four constructs shows that most of the respondents worry about getting infected with $H B V$, the perceived severity level is high among respondents, they perceived benefit from getting an $H B$ vaccination and perceived low barriers to getting the $H B$ vaccination.
\end{abstract}

Keyword: Vaccine perception, Adult Hepatitis B vaccination, Health Belief Model, Validity, Reliability, Factor analysis

\section{INTRODUCTION}

Hepatitis is a viral infection that results in the inflammation of the liver. The World Health Organisation (WHO) estimated that 240 million people chronically were infected by the Hepatitis B virus (HBV), especially in low and middle-income countries; 650,000 individuals die each year due to liver cirrhosis or hepatocellular carcinoma ${ }^{1}$. In Malaysia, an estimated one million nationals are chronically infected with HBV 2. It can be said that the Expanded Programme on Immunisation (EPI) implemented by the Malaysian government in 1989 was an HB vaccination initiative for infants 2,3 . Among individuals born before 1989 (and therefore were not covered under the compulsory HB vaccination programme) are currently aged or more. These Malaysians should be immunized against the HBV so that they may prevent infection and promote a healthy and, therefore, productive workforce.

Medical occupations in Malaysia should require that all medical personnel have compulsory HB vaccinations due to their exposure to the HBV and its occupational risk. Most health care workers are aware of the risk of $\mathrm{HB}{ }^{4,5}$, but initially, it was not well received by Malaysian dental practitioners, for example, due to their fear of plasma-derived HB vaccines ${ }^{6}$. Examining the Malaysians' perception of vaccination is there for every important to determine their behaviour regarding immunisation, especially for the $\mathrm{HB}$ vaccination. It is obvious therefore that the adult immunization practices and risk perception important in understanding of decision making on immunization to prevent the spread of immunological diseases ${ }^{7}$. In fact, most of the HB infections among medical staff are caused by direct exposure from HB infected patients ${ }^{8}$. Because most of the studies only 
gave priority to analysing this issue from an occupational risk perspective, consumers' perceptions for Hepatitis B vaccination is still lacking. Nevertheless, Larson et $\mathrm{al}^{9}$ highlighted that public trust on vaccination always changes and it depends on vaccine perception, vaccine risk experiences of getting the vaccine, religious or political situations and socioeconomic status.

Perception is described as an individual's belief regarding his or her own 'attributes' and 'interpretation' of behaviour ${ }^{10}$. Belief has a relationship between socialization and behaviour 11. Individual belief is based on an individual's characteristics that can be observed through one's behaviour and primary socialization. Lewin's "seminal field theory 1935" is one of the earliest theories in health behaviour ${ }^{12}$. The theories of Kurt Lewin explained that an individual's behaviour depends on the individual and the environment ${ }^{13}$. The Health Belief Model (HBM), developed by Godfrey Hochbaum, is based on Kurt Lewin's theories and explain that the perception of an individual is a very important determinant in individual reaction ${ }^{14}$. In this study, the perception of an individual on $\mathrm{HB}$ and adult $\mathrm{HB}$ vaccination was analysed using the Health Belief Model.

\section{METHODS}

The original questionnaire was developed in English language based on a literature review. The final versions of the questionnaire consisted of 33 questions. Questions on household perception were presented to respondents with a seven-point Likert scale with the choice of 1 for 'strongly disagree' and 7 for 'strongly agree' answer format.

\section{Validity}

In order to determine construct validity, the questionnaire was developed based on a literature review with a few more questionnaires added related to the study in the English language during the first stage. At the second stage, the English language questionnaire was translated into the Malay language. At the third stage, a panel consisted of medical microbiology, public health medicine and nephrology medical experts who were appointed to moderate and validate the content of the questionnaire. A series of discussion sessions were carried out face to face with moderators before concluding the pilot version of the revised questionnaire at the fourth stage. At the final stage, the finalized questionnaire was used for pilot testing.

\section{Data collection}

The questionnaire consists of two parts. The first part consists of socio-demographic information and the second part focuses on perception of Hepatitis B infection and the Hepatitis B vaccination. The data was collected randomly from six districts, namely Kajang, Cheras, Cyberjaya, Batu Caves, Rawang and Klang. The pilot test was conducted via face to face with 300 households selected randomly in these areas. The selection of the sample size for the pilot test was based on Nunnaly ${ }^{15}$, who recommended 300 subjects for factor analysis.

\section{Statistical analysis}

The data were analysed using Statistical Package for Social Sciences (SPSS) version 22. The frequency analysis was conducted for each socio demographic parameter, such as age, gender, race, marital status, employment status, education level, number of family members and household income. For the reliability test, the corrected item-total correlation using Cronbach alpha coefficient was conducted to ensure internal consistency. This study also employed Cronbach alpha to evaluate validity and accuracy of the questionnaire. This approach was recommended by Tavakol and Dennick ${ }^{16}$. Factor analysis was conduct to finalize the items in the analytic construct.

\section{RESULTS}

A total of 300 households participated in this study. The majority of respondents were male $57 \%(n=172)$; females represented $43 \% \quad(n=128)$ of the sample. The mean (SD) age of households was 41.5 (11.82) years; $\min =25 ; \max =83$; mode 32 . The vast majority of respondents were Malay $61 \%(n=182)$, followed by Chinese $27 \%$ $(n=82)$, Indians $12 \%(n=35)$ and others $1 \%(n=1)$. Most of respondents were married $79 \%(n=236)$, had a secondary education $51 \%(n=153)$ and were self-employed $28 \%(n=84)$ (Table 1$)$.

\section{Factor Analysis}

All requirements for factor analysis were fulfilled. The Kaiser-Meyer-Olkin criterion was 0.727 , which indicated accuracy of our sample size to conduct principal component analysis (PCA) and Bartlett's test was significant (Chisquare $=889.06$; degree of freedom $=78$; $\mathrm{p}<0.001)$. The PCA with VARIMAX rotation was performed for the 33 items $(6$ items from the construct of perceived susceptibility, 8 items from the perceived severity construct, 6 items from perceived benefit construct and 13 items from perceived barriers construct). For the VARIMAX rotation method, all items showed clear loading $(>0.60)$ on one of the four factors loading (Table 2). However, loading of 0.5 and more are considered acceptable (Hair et al., 1987). 
Table 1: Socio demographic characteristics of household

\begin{tabular}{|c|c|c|}
\hline Variable & Frequency & Percentage (\%) \\
\hline \multicolumn{3}{|l|}{ Gender } \\
\hline Male & 172 & 57 \\
\hline Female & 128 & 43 \\
\hline \multicolumn{3}{|l|}{ Age } \\
\hline $25-34$ & 101 & 34 \\
\hline $35-44$ & 84 & 28 \\
\hline $45-54$ & 67 & 22 \\
\hline $55-64$ & 36 & 12 \\
\hline 65 and above & 12 & 4 \\
\hline \multicolumn{3}{|l|}{ Ethnicity } \\
\hline Malay & 182 & 61 \\
\hline Chinese & 82 & 27 \\
\hline Indian & 35 & 12 \\
\hline Others & 1 & 1 \\
\hline \multicolumn{3}{|l|}{ Marital status } \\
\hline Married & 236 & 79 \\
\hline Single & 52 & 17 \\
\hline Widow & 3 & 1 \\
\hline Divorced & 9 & 3 \\
\hline \multicolumn{3}{|l|}{ Employment status } \\
\hline Self-employment & 84 & 28 \\
\hline Private sectors & 70 & 23 \\
\hline Unemployed & 63 & 21 \\
\hline Public sectors & 43 & 14 \\
\hline Retired & 23 & 8 \\
\hline Student & 5 & 2 \\
\hline Others & 12 & 4 \\
\hline \multicolumn{3}{|l|}{ Educational level } \\
\hline Never been to school & 5 & 1 \\
\hline Primary & 17 & 6 \\
\hline Secondary education & 153 & 51 \\
\hline Diploma/ certificate & 66 & 22 \\
\hline Degree holder & 44 & 15 \\
\hline Postgraduate & 15 & 5 \\
\hline \multicolumn{3}{|l|}{ Family income } \\
\hline$<$ RM1000 & 22 & 8 \\
\hline RM1001- RM2000 & 61 & 20 \\
\hline RM2001- RM3000 & 64 & 21 \\
\hline RM3001- RM4000 & 47 & 16 \\
\hline RM4001 - RM5000 & 39 & 13 \\
\hline$>$ RM5001 & 67 & 22 \\
\hline
\end{tabular}

The four extracted dimensions with PCA of the 33 items explain $39 \%$ of total variance with $14.8 \%$ explained by perceived susceptibility, $9.2 \%$ by perceived severity, $7.5 \%$ by perceived benefit and $7.5 \%$ by perceived barriers. PCA of the finalised 13 items explained the instrument of the variance, which was $59.7 \%$ in total, with $20.3 \%$ (perceived susceptibility), $14.5 \%$ (perceived severity), $12.5 \%$ (perceived benefit) and $12.4 \%$ (perceived barriers) explained by the four constructs (Table 3 ). Based on the initial PCA of 33 items, 20 items were deleted ( 3 items from perceived susceptibility, 5 items from perceived severity, 2 items from perceived benefit and 10 items from perceived barriers). 
Table 2: Result of the VARIMAX rotated factor loading matrix

\begin{tabular}{lcccc}
\hline Statement & \multicolumn{4}{c}{ Component } \\
\cline { 2 - 5 } & $\begin{array}{c}\mathbf{1} \\
\text { "Perceived } \\
\text { susceptibility" }\end{array}$ & $\begin{array}{c}\mathbf{2} \\
\text { "Perceived } \\
\text { severity" }\end{array}$ & $\begin{array}{c}\mathbf{3} \\
\text { "Perceived } \\
\text { benefit" }\end{array}$ & $\begin{array}{c}\mathbf{4} \\
\text { “Perceived } \\
\text { barriers" }\end{array}$ \\
\hline PS3 & & & 0.737 & \\
PS4 & & & 0.795 & \\
PS5 & & 0.784 & 0.552 & \\
PSE2 & & 0.765 & & \\
PSE3 & & 0.709 & & \\
PSE6 & 0.751 & & & \\
PBE2 & 0.789 & & & \\
\hline PBE3 & 0.857 & & & \\
PBE4 & 0.738 & & & \\
PBE5 & & & & \\
PB6 & & & & \\
PB8 & & & & \\
PB13 & & & & \\
\hline
\end{tabular}

Table 3: Variance explained by components

\begin{tabular}{lccc}
\hline Component & \multicolumn{3}{c}{ Extraction sums of squared loadings } \\
\cline { 2 - 4 } & Total & \% of variance & Cumulative \% \\
\hline 33 items instrument & & & \\
1 & 4.9 & 14.8 & 14.8 \\
2 & 3.0 & 9.2 & 23.9 \\
3 & 2.5 & 7.5 & 31.5 \\
4 & 2.5 & 7.5 & 39.0 \\
13 items instrument & & & \\
1 & 2.6 & 20.3 & 20.3 \\
2 & 1.9 & 14.5 & 34.8 \\
3 & 1.6 & 12.5 & 47.2 \\
4 & 1.6 & 12.4 & 59.7 \\
\hline
\end{tabular}

Reliability and validity of perception

The result of Cronbach alpha revealed that items in the four (4) components were internally reliable and indicated that items within the components were highly interrelated with Cronbach alpha more than 0.5 for each subscale (Table 4).

Most of the respondents neutral in perceived that they less likely than most people to get infected with HB $(n=61 ; 20.3 \%)$ and their body could fight off HB infection $(n=58 ; 19.3 \%)$. Nevertheless, most of respondent strongly disagree that they never worry about getting infected with HB $(n=74 ; 24.7 \%)$. This shows that most of the respondents worry about getting infected with HBV.

The vast majority of households strongly agree and perceived that their ethic group is at higher risk $(n=123 ; 41 \%)$ than other ethnicities, HB infection is a serious disease $(n=164 ; 54.7 \%)$, and also belief that there is cure for HB infection $(n=$
128; 42.7\%). This show that the household perceived seriousness with HB infection.

Most of the households strongly agree that HB vaccination reduces worry about liver diseases $(n=115 ; 38.3 \%)$, believe in the effectiveness of current $H B$ vaccinations $(n=106 ; 35.3 \%)$; that the $H B$ vaccination strengthens the immune system against $\mathrm{HBV}(\mathrm{N}=112 ; 37.3 \%)$ and that getting the $H B$ vaccine is a good way to protect themselves from HBV infection $(n=120 ; 40 \%)$. This shows that most of the respondents know about the benefit of the HB vaccination.

Households strongly disagree with the statement where to get the HB vaccination $(n=104 ; 34.7 \%)$, vaccination not effective for them $(n=84 ; 28 \%)$ and that their body can be weakened because of too many vaccinations $(n=58 ; 19.3 \%)$. This shows that most of the households know where to get an $\mathrm{HB}$ vaccination, they believe that vaccination is effective for them and their body not be weakened by vaccination. 
Table 4: Frequency, percentage and Cronbach alpha for each item

\begin{tabular}{|c|c|c|c|c|c|c|c|c|}
\hline \multirow{2}{*}{\multicolumn{2}{|c|}{ Subscales and items }} & \multicolumn{7}{|c|}{$\mathrm{n}(\%)$} \\
\hline & & $\begin{array}{l}\text { Strongly } \\
\text { disagree }\end{array}$ & Disagree & $\begin{array}{c}\text { Some } \\
\text { what } \\
\text { disagree }\end{array}$ & $\begin{array}{l}\text { Neither } \\
\text { agree or } \\
\text { disagree }\end{array}$ & $\begin{array}{c}\text { Somewhat } \\
\text { agree }\end{array}$ & Agree & $\begin{array}{c}\text { Strongly } \\
\text { agree }\end{array}$ \\
\hline \multicolumn{9}{|c|}{$\begin{array}{l}\text { Perceived Susceptibility } \\
(\text { Cronbach alpha }=0.508)\end{array}$} \\
\hline PS3 & $\begin{array}{l}\text { I am less likely than } \\
\text { most people to get } \\
\text { infected with HB }\end{array}$ & $\begin{array}{c}38 \\
(12.7 \%)\end{array}$ & $\begin{array}{c}44 \\
(14.7 \%)\end{array}$ & $\begin{array}{c}30 \\
(10 \%)\end{array}$ & $\begin{array}{c}61 \\
(20.3 \%)\end{array}$ & $\begin{array}{c}36 \\
(12 \%)\end{array}$ & $\begin{array}{c}54 \\
(18 \%)\end{array}$ & $\begin{array}{c}37 \\
(12.3 \%)\end{array}$ \\
\hline PS4 & $\begin{array}{l}\text { My body could fight } \\
\text { off HB infection. }\end{array}$ & $\begin{array}{c}43 \\
(14.3 \%)\end{array}$ & $\begin{array}{c}43 \\
(14.3 \%)\end{array}$ & $\begin{array}{c}24 \\
(8 \%)\end{array}$ & $\begin{array}{c}58 \\
(19.3 \%)\end{array}$ & $\begin{array}{c}55 \\
(18.3 \%)\end{array}$ & $\begin{array}{c}45 \\
(15 \%)\end{array}$ & $\begin{array}{c}32 \\
(10.7 \%)\end{array}$ \\
\hline $\begin{array}{l}\text { Perce } \\
\text { (Cron }\end{array}$ & $\begin{array}{l}\text { I never worry about } \\
\text { getting infected with } \\
\text { HB } \\
\text { ived Severity } \\
\text { Jach alpha }=0.678 \text { ) }\end{array}$ & $\begin{array}{c}74 \\
(24.7 \%)\end{array}$ & $\begin{array}{c}58 \\
(19.3 \%)\end{array}$ & $\begin{array}{c}28 \\
(9.3 \%)\end{array}$ & $\begin{array}{c}30 \\
(10 \%)\end{array}$ & $\begin{array}{c}34 \\
(11.3 \%)\end{array}$ & $\begin{array}{c}35 \\
(11.7 \%)\end{array}$ & $\begin{array}{c}41 \\
(13.7 \%)\end{array}$ \\
\hline PSE2 & $\begin{array}{l}\text { I belief that my } \\
\text { ethnic group at } \\
\text { higher risk of HB } \\
\text { infection }\end{array}$ & $\begin{array}{c}11 \\
(3.7 \%)\end{array}$ & $\begin{array}{c}24 \\
(8 \%)\end{array}$ & $\begin{array}{c}22 \\
(7.3 \%)\end{array}$ & $\begin{array}{c}17 \\
(5.7 \%)\end{array}$ & $\begin{array}{c}32 \\
(10.7 \%)\end{array}$ & $\begin{array}{c}71 \\
(23.7 \%)\end{array}$ & $\begin{array}{l}123 \\
(41 \%)\end{array}$ \\
\hline PSE3 & $\begin{array}{l}\text { I belief that HB } \\
\text { infection is serious } \\
\text { disease }\end{array}$ & $\begin{array}{c}7 \\
(2.3 \%)\end{array}$ & $\begin{array}{c}9 \\
(3 \%)\end{array}$ & $\begin{array}{c}18 \\
(6 \%)\end{array}$ & $\begin{array}{c}29 \\
(9.7 \%)\end{array}$ & $\begin{array}{c}31 \\
(10.3 \%)\end{array}$ & $\begin{array}{c}42 \\
(14 \%)\end{array}$ & $\begin{array}{c}164 \\
(54.7 \%)\end{array}$ \\
\hline PSE6 & $\begin{array}{l}\text { I believe that there } \\
\text { is a cure for } \mathrm{HB} \\
\text { infection }\end{array}$ & $\begin{array}{c}13 \\
(4.3 \%)\end{array}$ & $\begin{array}{c}15 \\
(5 \%)\end{array}$ & $\begin{array}{c}11 \\
(3.7 \%)\end{array}$ & $\begin{array}{c}9 \\
(3 \%)\end{array}$ & $\begin{array}{c}36 \\
(12 \%)\end{array}$ & $\begin{array}{c}88 \\
(29.3 \%)\end{array}$ & $\begin{array}{c}128 \\
(42.7 \%)\end{array}$ \\
\hline \multicolumn{9}{|c|}{$\begin{array}{l}\text { Perceived Benefit } \\
(\text { Cronbach alpha }=0.823)\end{array}$} \\
\hline PBE2 & $\begin{array}{l}\text { If I take the HB } \\
\text { vaccine it will } \\
\text { reduce my worry } \\
\text { about liver disease }\end{array}$ & $\begin{array}{c}6 \\
(2 \%)\end{array}$ & $\begin{array}{c}7 \\
(2.3 \%)\end{array}$ & $\begin{array}{c}15 \\
(5 \%)\end{array}$ & $\begin{array}{c}24 \\
(8 \%)\end{array}$ & $\begin{array}{c}40 \\
(13.3 \%)\end{array}$ & $\begin{array}{c}93 \\
(31 \%)\end{array}$ & $\begin{array}{c}115 \\
(38.3 \%)\end{array}$ \\
\hline PBE3 & $\begin{array}{l}\text { I believe on the } \\
\text { effectiveness of HB } \\
\text { vaccine now }\end{array}$ & $\begin{array}{c}12 \\
(4 \%)\end{array}$ & $\begin{array}{c}9 \\
(3 \%)\end{array}$ & $\begin{array}{c}9 \\
(3 \%)\end{array}$ & $\begin{array}{c}38 \\
(12.7 \%)\end{array}$ & $\begin{array}{c}61 \\
(20.3 \%)\end{array}$ & $\begin{array}{c}65 \\
(21.7 \%)\end{array}$ & $\begin{array}{c}106 \\
(35.3 \%)\end{array}$ \\
\hline PBE4 & $\begin{array}{l}\text { I believe a vaccine } \\
\text { HB strengthen } \\
\text { immune system } \\
\text { against HBV }\end{array}$ & $\begin{array}{c}8 \\
(2.7 \%)\end{array}$ & $\begin{array}{c}12 \\
(4 \%)\end{array}$ & $\begin{array}{c}11 \\
(3.7 \%)\end{array}$ & $\begin{array}{l}27 \\
(9 \%)\end{array}$ & $\begin{array}{c}45 \\
(15 \%)\end{array}$ & $\begin{array}{c}85 \\
(28.3 \%)\end{array}$ & $\begin{array}{c}112 \\
(37.3 \%)\end{array}$ \\
\hline PBE5 & $\begin{array}{l}\text { I believe that getting } \\
\text { Hepatitis B vaccine is } \\
\text { a good way to } \\
\text { protect yourself from } \\
\text { HBV infection }\end{array}$ & $\begin{array}{c}9 \\
(3 \%)\end{array}$ & $\begin{array}{c}12 \\
(4 \%)\end{array}$ & $\begin{array}{c}19 \\
(6.3 \%)\end{array}$ & $\begin{array}{c}15 \\
(5 \%)\end{array}$ & $\begin{array}{c}37 \\
(12.3 \%)\end{array}$ & $\begin{array}{c}88 \\
(29.3 \%)\end{array}$ & $\begin{array}{c}120 \\
(40 \%)\end{array}$ \\
\hline \multicolumn{9}{|c|}{$\begin{array}{l}\text { Perceived Barriers } \\
(\text { Cronbach alpha }=0.535)\end{array}$} \\
\hline PB6 & $\begin{array}{l}\text { I believe that } \\
\text { vaccination is not } \\
\text { effective for me }\end{array}$ & $\begin{array}{c}83 \\
(27.7 \%)\end{array}$ & $\begin{array}{c}84 \\
(28 \%)\end{array}$ & $\begin{array}{c}28 \\
(9.3 \%)\end{array}$ & $\begin{array}{c}43 \\
(14.3 \%)\end{array}$ & $\begin{array}{c}35 \\
(11.7 \%)\end{array}$ & $\begin{array}{c}11 \\
(3.7 \%)\end{array}$ & $\begin{array}{c}16 \\
(5.3 \%)\end{array}$ \\
\hline PB8 & $\begin{array}{l}\text { I don't know where } \\
\text { to get the HB } \\
\text { vaccine }\end{array}$ & $\begin{array}{c}104 \\
(34.7 \%)\end{array}$ & $\begin{array}{c}48 \\
(16 \%)\end{array}$ & $\begin{array}{c}23 \\
(7.7 \%)\end{array}$ & $\begin{array}{c}17 \\
(5.7 \%)\end{array}$ & $\begin{array}{c}24 \\
(8 \%)\end{array}$ & $\begin{array}{c}34 \\
(11.3 \%)\end{array}$ & $\begin{array}{c}50 \\
(16.7 \%)\end{array}$ \\
\hline PB13 & $\begin{array}{l}\text { I believe that my } \\
\text { body's immune } \\
\text { system can be } \\
\text { weakened because } \\
\text { too many } \\
\text { vaccinations }\end{array}$ & $\begin{array}{c}58 \\
(19.3 \%)\end{array}$ & $\begin{array}{c}60 \\
(20 \%)\end{array}$ & $\begin{array}{c}24 \\
(8 \%)\end{array}$ & $\begin{array}{c}57 \\
(19 \%)\end{array}$ & $\begin{array}{c}35 \\
(11.7 \%)\end{array}$ & $\begin{array}{c}34 \\
(11.3 \%)\end{array}$ & $\begin{array}{c}32 \\
(10.7 \%)\end{array}$ \\
\hline
\end{tabular}




\section{DISCUSSION}

The objective of this pilot study was to determine the reliability and validity of the Malay version of the perception questionnaire used among Malaysian households. Hair et al. ${ }^{17}$ defines reliability as the "extent to which variables or a set of variables is consistent in what it is intend to measure" (pp.93). A Cronbach's alpha value of 0.5 and higher is considered acceptable ${ }^{18}$, however, a score of 0.6 and 0.7 is a good indicator of reliability ${ }^{17}$. The reliability of the questionnaire for this study was considered to have moderate internal consistency ${ }^{19}$ and has sufficient to acceptable value for research purposes ${ }^{15}$ because the overall Cronbach's alpha was 0.6.

PCA of the finalised 13 items explained the instrument of the variance, which was $59.7 \%$ in total, with perceived sustainability being $20.3 \%$, perceived severity $14.5 \%$, perceived benefit $12.5 \%$ and perceived barrier $12.4 \%$. The minimum acceptable factor loading can be 0.30 and above ${ }^{16}$ and 0.5 and more is considered acceptable ${ }^{17}$. However, in this study values of factor loading in the range of 0.5 to 0.8 which indicated an acceptable range.

The frequency analysis for each construct shows that Malaysian households do not know the risk of $\mathrm{HB}$ infection with the answer neutral for perceived sustainability. Yet, they know about the seriousness of HB infection with the answer strongly agree for perceived severity items with highest percentage. This study finding similar to a study conducted on across four Asian American group revealed that the household the highest perceived susceptibility and severity for HB infection ${ }^{20}$. Moreover, household perceived benefit with $H B$ vaccination reduce the chances of $H B$ infection with the answer strongly agree for perceived benefit. Nevertheless, Malaysian household perceived that no obstacles to vaccinated with the answer disagree for perceived barriers items. This study finding supported by the new path of perceived barriers to perceived benefit of HB vaccination $^{21}$, were if the household perceived no barriers will increase the perceived benefit of get $H B$ vaccination.

\section{CONCLUSION}

This study shows that the Malay version of the perception questionnaire is valid and acceptable for determining the perceived sustainability, perceived severity, perceived benefit and perceived barriers of $\mathrm{HB}$ and adult $H B$ vaccination among Malaysian households.

\section{Conflict of interest}

The authors declare no potential conflict of interest.

\section{Acknowledgement}

This study was funded by the Putra Grant Putra Graduate Initiative (IPS), grant number GP-IPS/2013-939220. The authors would like to thank the all respondents who agreed to participate in this study and the questionnaire moderator's committee from the Faculty of Health Sciences, Universiti Putra Malaysia: Dr. Anim Md. Shah, Nephrology Department and Dr. Salmiah Md. Said, Department of Community Health.

\section{REFERENCE}

1. Ministry of Health Malaysia. Health Facts 2014. Available from: http: :http://www.moh.gov.my/images/gal lery/publications/HEALTH\%20FACTS\% 202014.pdf

2. Khairullah NS, \& Merican DI. Hepatitis disease management programs in Malaysia. Journal of gastroenterology and hepatology, 2004; 19(S1),S13-S16

3. Ng KP, Saw TL, Baki A, Rozainah K, Pang KW, \& Ramanathan M. Impact of the Expanded Program of Immunization against hepatitis B infection in school children in Malaysia. Medical microbiology and immunology, 2005; 194(3),163-168.

4. Hesham R, Zamberi S, Tajunisah ME, Ariza A, \& Ilina I. Hepatitis B immunisation status among health care workers in two Kuala Lumpur hospitals. The Medical journal of Malaysia, 2005; 60(4), 407-410.

5. Lim HC \& Rashwan H. Awareness of Hepatitis A and Hepatitis B among Residents in Kuala Lumpur and Selangor. Malaysian Journal of Pharmacy, 2003; 1(3), 76-85

6. Yaacob HB \& Samaranayake LP. Awareness and acceptance of the hepatitis B vaccine by dental practitioners in Malaysia. Journal of 
Oral Pathology \& Medicine1989; 18(4), 236-239.

7. Hanslik T, Wechsler B, Vaillant JN, Audrain L, Prinseau J, Baglin A, \& Flahault A. A survey of physicians' vaccine risk perception and immunization practices for subjects with immunological diseases. Vaccine, 2000; 19(7), 908-915.

8. Holmberg SD, Suryaprasad A, Ward JW. Updated CDC recommendations for the management of hepatitis $B$ virus-infected health-care providers and students. Morbidity and Mortality Weekly Report: Recommendations and Reports. 2012 Jul 6;61(3):1-2..

9. Larson HJ, Louis ZC, Juhani Eskola, Samuel LK, and Scott Ratzan. "Addressing the vaccine confidence gap." The Lancet,2011; 378, 201, 526535

10. Molden DC, \& Dweck CS. Finding" meaning" in psychology: a lay theories approach to self-regulation, social perception, and social development. American Psychologist, 2006; 61(3), 192-201

11. Abraham C, \& Sheeran P. Predicting health behavior. In Conner, $M$ \& Norman, $P$ (Eds), The health belief model, McGraw-Hill International, 2005; $28-80$

12. Rimer BK. Models of individual health behavior. Health Behavior and Health Education: Theory, Research and Practice, 2008; 41-45.

13. Sansone C, Morf CC, \& Panter AT (Eds.). The Sage handbook of methods in social psychology. Sage Publications.2003.

14. Hochbaum G, Rosenstock I, \& Kegels $S$. Health belief model. United States Public Health Service. 1952.
15. Nunnallyn JC, Psychometric theory, 1978; New York: McGraw-Hill.

16. Tavakol M, \& Dennick R. Making sense of Cronbach's alpha. International journal of medical education, 2011; (2)53-55.

17. Hair JF, Black WC, Babin BJ, \& Anderson RE. (2010). Multivariate Data Analysis. Seventh Edition, 2010. Prentice Hall, Upper Saddle River, New Jersey

18. Bowling A. Research methods in health: investigating health and health services. McGraw-hill education (UK); 2014 Jul 1.

19. Pielak KL, \& Hilton A. University students immunized and not immunized for measles: a comparison of beliefs, attitudes, and perceived barriers and benefits. Canadian Journal of Public Health/Revue Canadienne de Sante'e Publique, 2003; 193-196.

20. Maxwell AE, Stewart SL, Glenn BA, Wong WK, Yasui Y, Chang LC, Taylor VM, Nguyen TT, Chen Jr MS, Bastani R. Theoretically informed correlates of hepatitis B knowledge among four Asian groups: the health behavior framework. Asian Pacific journal of cancer prevention: APJCP. 2012;13(4):1687.

21. Rajamoorthy $Y$, Radam A, Taib NM, Rahim KA, Wagner AL, Mudatsir M, Munusamy S, Harapan $H$. The relationship between perceptions and self-paid hepatitis B vaccination: A structural equation modeling approach. PLoS One. 2018 Dec 6;13(12):e0208402. 